\title{
BYĆ OBCYM U SIEBIE? MARCIN ŚWIETLICKI I BARBARA GRUSZKA-ZYCH WOBEC ZNAKÓW PRZYNALEŻNOŚCI
}

\section{SŁOWA KLUCZOWE}

Marcin Świetlicki; Barbara Gruszka-Zych; polska poezja współczesna; poezja francuska; znak; symbol; przynależność; obcość; kultura; akulturacja

Akceptacja tego, co własne wydaje się być podstawowym odruchem uczestników każdej kultury, wyrażającym się w śmiałym korzystaniu ze wspólnotowych narracji, instytucji i symboli. A jednak, podważenie roli i prawomocności znaków rozpoznawczych własnej formacji kulturowej stało się jednym z najważniejszych syndromów nowoczesnego świata zachodniego. Proces ów przebiegał stopniowo, prowadząc w końcu do sugestii, że symbole przynależności służą głównie temu, by narzucać je innym. Co może uczynić obarczony taką świadomością człowiek? Czy rozwiązaniem byłby wybór jakiejś innej kultury, religii, otoczenia społecznego, czy raczej projekt nowego, a-symbolicznego świata, w którym nie trzeba będzie wybierać? A może należałoby jednak próbować odnaleźć się na nowo w porzuconej przez siebie kulturze? Pytania te zostaną zadane w obecności — i przy udziale — dwojga wymienionych w tytule współczesnych polskich poetów. Najpierw jednak kilka uwag, odnoszących się do ideowego i wyobrażeniowego tła problematyki przynależności i obcości.

Stanisław Jasionowicz — dr hab., prof. Uniwersytetu Pedagogicznego w Krakowie, Instytut Neofilologii UP w Krakowie, Pracownia Badań Porównawczych nad Współczesną Kulturą Zachodnią; e-mail: stanislaw.jasionowicz@up.krakow.pl 


\section{Partycypacja, kontestacja, zawłaszczenie}

Podważenie przez europejskich symbolistów - owych prekursorów nowoczesności - tradycyjnych systemów kulturowych konotacji nie oznaczało jeszcze radykalnej kontestacji znaczeń własnej kultury, ale stanowiło próbę odwołania się do wartości symbolu, przekraczającej jego postrzeganie jako „znaku rozpoznawczego" konkretnej formacji kulturowej i uznanie go za niepoddającą się jakiemukolwiek lokalnemu zawłaszczeniu, wieloznaczną epifanię Niepoznawalnego $^{1}$. Warto zauważyć, że podniesienie na nowo przez francuskich i belgijskich artystów końca XIX stulecia symbolu do tak wysokiej rangi nie miało wymiaru jakiejś mistycznej krucjaty, a było po części krytyczną reakcją wobec efektów zawłaszczenia przez burżuazję religijno-kulturowych treści oraz znaczeń, wypracowanych przez społeczeństwo przedrewolucyjne i zredukowania ich do skostniałych, zakłamanych, „,filisterskich” form.

Czynnikiem, sprzyjającym postawie „stanięcia poza” jest sytuacja emigracji i poczucie „bycia wygnanym”. To często wymuszony okolicznościami, a czasem świadomie podjęty los wielu ludzi, pośród nich także artystów, poszukujących nowego języka sztuki poprzez odwołanie się do kategorii „obcości”. Europejscy twórcy artystycznych awangard początku XX wieku byli poniekąd takimi uciekinierami: zarówno z krajów ogarniętych światową wojną, podczas której ważyły się losy starej Europy, jak też ze swych „zatęchłych” burżuazyjnych domów w Paryżu, Brukseli czy Bukareszcie. Początkowo było to jedynie poszukiwanie „enklaw wolności”, pozwalających swobodnie poigrać z symbolami, które stawały się w ich oczach martwymi, fałszywymi znakami. Z czasem zaowocowało to próbami rozciągnięcia własnego stanu świadomości na cały zajmowany przez siebie obszar kulturowy z nadzieją przekucia owej inności w nową, wspólnotową jakość — swoistą międzynarodówkę pogardy wobec dotychczasowych sensów i znaków przynależności.

W swoim, opublikowanym w roku 1913, słynnym poemacie Strefa (Zone) Guillaume Apollinaire — ów kosmopolita o włosko-polskich korzeniach i poliglota o rozległych horyzontach kulturowych — ogłasza Francuzom swoje (a może: ich?) własne zniecierpliwienie „starą Europą”:

$\mathrm{Na}$ koniec starodawny ten świat ci się przejada

[...]

Grecka i rzymska starożytność twojego nie nasyci głodu

Tutaj starzyzną trąci już nawet widok samochodu

Religia się jedna została nowsza nad wszystko

Religia prosta pozostała jak hangar na lotnisku

1 W dalszej konsekwencji doprowadziło to jednak do zaprzeczenia samej „funkcji symbolicznej”. Na temat funkcji symbolicznej, por. np. prace Ernsta Cassirera i Carla-Gustava Junga. 
O chrześcijaństwo ty jedno w Europie zakwitasz świeżo

Najbardziej modernistycznym Europejczykiem jesteś ty Piusie X Papieżu

A ciebie którego dziś rano każde oko śledzi

Wstyd powstrzymuje od pójścia do kościoła i do spowiedzi

(Apollinaire 1975: 37)

Rozgorączkowanemu piewcy nowoczesności samochody zdają się być przestarzałe już w drugim dziesięcioleciu dwudziestego wieku, lecz jednocześnie Chrystus staje się dla niego „pierwszym lotnikiem”, a papież Pius X, przeciwnik aggiornamento - dynamicznym kontrapunktem dla wizji bezalternatywnej, kontestującej tradycję, nowoczesności. Apollinaire, zwany często odnowicielem liryki francuskiej, sugeruje możliwość zachowania przez nowoczesnego poetę więzi pomiędzy „dawnymi a młodszymi laty”, a istotą nowej poezji będzie twórcze czerpanie — „tu i teraz” — ze wszystkich dostępnych jej zasobów. U Apollinaire’a granica pomiędzy tym, co własne a tym, co „cudze” („obce”) staje się więc płynna, lecz chęć tworzenia „nowych symboli” w kolonialnej Francji, znajdującej się u szczytu swojej gospodarczej prosperity, podyktowana jest bardziej przekonaniem o konieczności dotrzymania kroku, przez wyobraźnię poetycką, wyzwaniom cywilizacji technicznej, niż chęcią całkowitej destrukcji dawnego świata.

Inni są bardziej radykalni w swoich poszukiwaniach „nowego”. W pochodzącym z roku 1946 wierszu Jacques'a Préverta, zatytułowanym Walka z aniotem (Le combat avec l'ange) samotny bohater szczególnej walki bokserskiej wykreowany jest na uczłowieczonego Chrystusa-buntownika, z góry skazanego na niesportowy nokaut ze strony wszechmocnej Władzy, reprezentowanej przez tajemniczego przeciwnika, wspieranego przez opresyjnych „nich” — francuskich „strasznych mieszczan”, znienawidzoną przez poetyckie ego poety tłuszczę popleczników katolickiego Boga Ojca:

\section{$[\ldots]$}

Cały ten mecz to szachrajstwo

I ledwie on się pojawi na ringu

W otoku błysków magnezji

Oni na całe gardło zaintonują TE DEUM

I jeszcze zanim wstaniesz z krzesełka w narożniku

Ogłoszą Twoją przegraną biciem we wszystkie dzwony

Rzucą ci prosto w twarz

Gąbkę przeklętą

I zanim zdołasz się jakoś dorwać do jego piórek

Rzucą się hurmem na ciebie

A wówczas on ci zada cios poniżej pasa

I zwalisz się jak długi 
Z ramionami pokracznie rozkrzyżowanymi

W trociny

I już nie będziesz mógł nigdy przespać się z dziewczyną

(Prévert 1978: 311)

Tak jednoznacznie ukazany podział ról, wynikający z chęci dostosowania przez anarchizującego poetę biblijnego motywu do potrzeb aktualnej polemiki społecznej - instrumentalne potraktowanie starotestamentowego motywu walki Jakuba z aniołem oraz chrześcijańskiego obrazu Chrystusowej męki - zaciera pierwotny sens przywoływanych scen. Jakkolwiek epizod z Księgi Rodzaju był od początku historii egzegezy biblijnej przedmiotem kontrowersji i licznych interpretacji wewnątrz formacji kulturowej, w której funkcjonował (i poniekąd funkcjonuje), to uznanie sytuacji Jakuba za analogiczną do sytuacji Chrystusa, „wysłanego na śmierć” przez Ojca i otoczonego nienawistnym tłumem jego popleczników (wyznawców), radykalnie pozbawia konkretne znaki kulturowe ich wewnętrznej logiki, wykorzystując jedynie ich zewnętrzny sztafaż w bieżącym sporze politycznym. Taki stosunek do symboli, funkcjonujących w jego własnej kulturze sprawia wrażenie poruszania się poety po obcym mu już terytorium. Przedmiotem kontestacji są tu oczywiście kody symboliczne chrześcijaństwa, lecz jednocześnie wiersz ten, jak zresztą cała twórczość Préverta, wyraża niechęć do jakichkolwiek mocnych („transcendujących”) znaków i narracji, postrzeganych jako narzędzia „symbolicznej przemocy”: w zamian artysta proponuje wizję znaków „niewinnych”, „neutralnych”, w postaci poetyckich obrazów codzienności oraz podstawowych, niezapośredniczonych ludzkich radości i trosk.

Już z końcem lat 50. dwudziestego wieku Roland Barthes postulował, by uznawać wszelkie systemy symboliczne i ich mityczne rozwinięcia za zawsze podejrzane „języki drugiego stopnia” (por. „langage(s) second(s)”), określając je jako „faszystowskie”, gdyż „zmuszają, by wybierać” (Barthes 2000; por. Barthes 1978). Twórca (poeta) nowoczesny, poszukujący swego miejsca w coraz bardziej obcym mu świecie jest wciąż rozdarty pomiędzy „buntem przeciw” a „buntem ku": już rewolucja francuska 1789 roku głosiła wolność od wszelkich znaków przeszłości, ale tworzyła zarazem nowy porządek, zawłaszczający wiele spośród symboli i narracji ancien régiméu. Kolejne realizacje idei, nakazującej zanegowanie dotychczasowych kodów kultury - marksizm, modernizm, idea światowej rewolucji - zmuszały przecież do dokonywania radykalnych wyborów: zmiany języka, wyparcia się pewnych kulturowych kodów, aby zastąpić je innymi, „właściwymi”.

Postulaty „oczyszczenia świadomości”, czy to za pomocą medytacji transcendentalnej, narkotyków, czy w akcie poetyckim znalazły swoją pełną ekspresję 
dopiero w dwudziestym wieku — w ruchach młodzieżowych lat 60. w Stanach Zjednoczonych, w krajach Europy Zachodniej i Środkowej oraz Ameryce Łacińskiej — ale i wtedy nigdy w całkowitym oderwaniu od historyczno-społeczno-kulturowo-politycznych uwarunkowań rejonu świata, w których się pojawiły. Wybór negacji coraz częściej znaczony jest jednak symbolami wspólnoty, będącymi zestawami signifiants, oderwanych od swoich signifiés. Oto na przykład dzieci kolejnego pokolenia zadowolonych bourgeois - młodzi paryscy buntownicy z maja 1968 roku głoszący, że odtąd „zabrania się zabraniać”, powołują się jednocześnie na czerwoną książeczkę Mao Tse Tunga — zawierającą doktrynę maksymalnego zniewolenia jednostki w oparciu o pseudonaukową ideologię zbawienia mas przez katorżniczą pracę.

W powojennej Polsce poetyka buntu i zaangażowania opierała się na dylematach oportunizmu i sprzeciwu, opowiadania się za „nową”, socjalistyczną, przywiezioną na obcych bagnetach ojczyzną lub kultywowania polskich symboli II Rzeczpospolitej w zupełnie nowym kontekście historycznym. $\mathrm{Z}$ początkiem lat 80. owa dychotomia sprowadzała się często do odpowiedzi na proste pytanie: „jesteś za Solidarnością czy za Partią”? Okres drugiej połowy lat osiemdziesiątych ubiegłego stulecia wraz z początkiem kolejnej dekady to z kolei czas, kiedy także niektórzy spośród młodych poetów spróbowali przezwyciężyć aporie tak rozumianej, dwubiegunowej wizji „bycia tu”. Charakterystycznym głosem przemówiło w tym czasie środowisko krakowskiego „bruLionu”. Ci młodzi Polacy nie wyemigrowali, zdecydowali się studiować historię polskiej kultury i literatury w starym uniwersyteckim mieście zamkniętego za „żelazną kurtyną” kraju Europy Środkowej, lecz jednocześnie chcieli znów wiosną, zamiast Polski, „wiosnę zobaczyć”. Powtarzając, w nowym kontekście, niektóre spośród gestów modernistów początku dwudziestego wieku, antycypowali oni dylematy artystyczne twórców pierwszych dekad następnego stulecia.

\section{Świetlicki, Gruszka-Zych: uniwersalne czy lokalne „znaki istnienia”?}

Dwoje poetów pokolenia lat 60. - Marcin Świetlicki i Barbara Gruszka-Zych to skupieni na kontemplacji własnych wewnętrznych stanów poetyccy egotyści, ale także wrażliwi obserwatorzy otaczającego ich świata. Świetlicki, uznający samego siebie za twórcę „trochę autystycznego" i podkreślający często swoją mizantropię oraz niechęć do świata, jest jednak mocno zaangażowany emocjonalnie w polską rzeczywistość. Gruszka-Zych, „otwarta na świat i ludzi” poetka, dziennikarka, sporo podróżująca reporterka, autorka książek o swoich „bliskich spotkaniach” z Czesławem Miłoszem i Wojciechem Kilarem, to autorka, dla której ważnym 
kontekstem twórczym są odkrywane przez nią i badane z perspektywy intymistycznej, znaki kulturowej tożsamości.

Gruszka-Zych i Świetlicki zetknęli się na krótko u progu swojej literackiej działalności, podczas organizowanych przez tygodnik „Na Przełaj” spotkań Klubu Młodych Autorów, jednak odtąd ich dalsze drogi przebiegają całkowicie odrębnie. Reprezentują dwa różne, choć komentujące się wzajemnie — jeśli nie komplementarne - światy odniesień, skojarzeń i znaczeń, a przede wszystkim, szczególny stosunek do symboli kulturowych, rozpatrywanych na tle znaków własnego istnienia.

Odwołanie się do cierpienia zdaje się być pierwotnym sposobem oznaczania przez oboje poetów parametrów własnego „bycia tu”. W wierszach Świetlickiego zdumienie faktem bycia wyraża się często jako doświadczenie fizycznego, namacalnego lęku. Ten punkt wyjścia, charakterystyczny dla nowoczesnej świadomości, stwarza ramy dla poetyckiego postrzegania świata w kategoriach zagrożenia. U Świetlickiego zdecydowanie dominuje skupienie na własnych przeżyciach egzystencjalnych, a jego podmiot poetycki (być może w imię swej męskiej powściągliwości) prawie nigdy nie odnosi się do fizycznego cierpienia innego człowieka. W twórczości Gruszki-Zych naturalne pytania egzystencjalne nie przybierają tak dramatycznie brzmiących tonów, choć w jej utworach nie brakuje odniesień do traumatycznych wydarzeń, jak choroba, pobyty w szpitalu i śmierć bliskich. Jej relacja ze światem jest warunkowana przez kategorię współczucia i solidarności z innymi w ich lękach i cierpieniach — a owa solidarność zdaje się dotyczyć także podmiotu lirycznego, który oswaja własne cierpienie, obserwując je z bliska ze szczególnym, można by rzec, reporterskim, zainteresowaniem.

\section{Być mężczyzną, być kobieta, mówić „tym” językiem: pierwszy krąg przynależności}

Oboje poeci znacząco często odwołują do doświadczenia własnej tożsamości płciowej oraz wyrażają przywiązanie do własnego języka. To kolejne znaki przynależności, doświadczane przez Świetlickiego i Gruszkę-Zych. Akceptacja własnej płci oraz waga, jaką każde z nich przywiązuje do „innego” w sensie płciowym, wiąże się także z dostrzeganiem kulturowych znaków, wyrażających tę relację.

Świetlicki w naturalny sposób, a czasem nieco demonstracyjnie (gdy pisze na przykład: „Mieszkam z tobą nie w ramach parytetu, kobieto” — Świetlicki 2016: 88) manifestuje swoją męską naturę w relacji z fascynującą go (czy tylko erotycznie?) kobiecością. „Bycie z kobietą” oznacza dla niego „stan naturalny”, a zarazem ideał harmonii, do którego wciąż dąży jego poetycki podmiot: 
W innym wszechświecie spotkałbym

siedmiogłowego woła

ośmiopenisowego tygrysa,

mógłbym się tam z nim związać.

Spokojnie.

Zanika młodzieńczy problem.

No i normalnie znajduję kobietę.

No i normalnie radzę sobie.

Spokojnie.

Moja płciowość

określiła się.

A nad tym wszystkim stoi

Pan Bóg

(Świetlicki 2013: 71, Pan Bóg)

Synonimem, a może raczej symbolem egzystencjalnego i kulturowego zakorzenienia staje się dla Świetlickiego relacja, której punktem odniesienia jest kobieta, jako fascynująca „obca” — znak czy też ślad możliwości Ładu, nadzieja na porządek istnienia.

Także Barbara Gruszka-Zych śmiało i z niekłamaną satysfakcją zagłębia się w meandry uczuć, erotycznych fascynacji, radości i niepokojów swej kobiecości. Zmysłowość, namiętny stosunek do rzeczywistości Gruszki-Zych wyraża się między innymi w pragnieniu harmonii, ukazywanej jako „rozpłynięcie się" w drugim:

ciałem w ciało

jak kamieniem w wodę

nie znajdziesz śladu

że było ich dwoje

(Gruszka-Zych 1997: 101, ***)

Nie oznacza to jednak dążenia do zatarcia, czy też negacji własnej tożsamości: miłość i potrzeba erotycznego spełnienia wyzwalają w poetce siłę, pozwalającą jej śmielej „przejrzeć się” w swoim doświadczeniu kobiecości i umocnić w ten sposób swoją samoidentyfikację:

zacząłeś mówić o kobiecie i mężczyźnie

dotąd nie przyznawaliśmy się do tego

dlatego dziś widzimy się

pierwszy raz

(Gruszka-Zych 1997: 38, ***) 
W przypadku Świetlickiego, jego dążenie do „bycia z kobietą”: „[...] przejdziemy przez siebie / w lepsze, gorące kraje, bo istnieją, skoro / ty zaistniałaś i ja już istnieję ..." (Świetlicki 2011: 148, Pogo), owo marzenie o spełnieniu jako swoistej „przedustawnej harmonii” powiązane jest z potrzebą „przeniknięcia się”, ale też przyjęcia tego, co owa „inność” oferuje - darem tym jest możliwość samoidentyfikacji: „ona mi daje życie / ona mi je robi” (Świetlicki 2013: 57, O). Jednocześnie harmonia ta narażona jest na liczne niebezpieczeństwa, do których należą zrytualizowane praktyki życia rodzinnego:

Dla mamy, żony, mamy żony, taty, taty żony i dzieci, pani dzieci ze szkoły siostry dzieci ze szkoły, golą się i robią w swojej robocie swoją robotę i jadą na długi weekend z mamą, żoną, mamą żony $[\ldots]$

Lecz nagle pęka śrubka, misterna konstrukcja w tej chwili grozi zawaleniem! Ale natychmiast przy pomocy żony, mamy żony i taty, brata żony, pani doktor i kilku przyjaciółek żony, pęknięcia jakoś daje się zasłonić, dalej się można golić, robić, spokój kazirodczy (Świetlicki 2013: 11, Śrubka)

Społeczne role mężczyzny, także widziane na tle nierzadkiej dominacji (a przynajmniej silnej pozycji) kobiet w polskiej rodzinie, zdają się go uwierać: pisząc o „zasłonięciu”, a nie na przykład „zabliźnieniu”, „naprawie”, czy choćby „załataniu” pęknięcia w grożącej zawaleniem rodzinnej konstrukcji poeta daje poza wszystkim wyraz swojemu niepokojowi, związanemu z osłabieniem roli mężczyzny we współczesnej rodzinie (a może w domu, zdominowanym przez kobiety?). Pytając jednocześnie o samą rodzinę jako instytucję społecznego przymusu, uznaje ją za jedną z protez, nieudolnie, jego zdaniem, eufemizujących dramat przemijania i śmierci:

[...] w cukrze jajo robaka, a pościel pokryta grzybem, grzyb zakrył inicjał na pościeli, co to ją mama albo inna kobieta $\mathrm{z}$ rodziny, jakiej rodziny? Jest tylko grzyb, robak (Świetlicki 2011: 117, To mnie umiera) 
Macierzyństwo i ojcostwo pozostawiło oczywiście swe ślady w poetyckim imaginarium obojga poetów, ale u każdego z nich w nieco odmienny sposób.

Gruszka-Zych akceptuje swoje macierzyństwo i obserwuje siebie jako matkę w całym przebiegu historii swojej relacji z dziećmi - począwszy od wiersza, pochodzącego z jej debiutanckiego tomiku: „między wilgocią sutki / a uchylonymi snem ustami / leniwa niteczka śliny / pępowina / którą znów znalazła / matka" (Gruszka-Zych 1994: 26, ${ }^{* * *}$ ) po ten, opublikowany w roku 2015: „chcę się wybrać z synem na spacer / pytam nieśmiało kiedy będzie miał czas / kiedyś to on mnie prosił żebym z nim wyszła" (Gruszka-Zych 2015: 26, *** — synowi Tymoteuszowi). Jej poetyckie obserwacje, odnoszące się do zmieniających się z czasem relacji z własnymi dziećmi są zarazem introspekcją jej stosunku do własnego przemijania.

Świetlicki, w nielicznych wierszach inspirowanych ojcostwem, zdaje się wyrażać zniecierpliwienie koniecznością spełniania rodzinnych rytuałów, a także niepokój, związany z możliwością stania się składnikiem „najmniejszej komórki społecznej” oraz uczestnikiem tak zwanego „procesu wychowawczego". W jego wierszu, zatytułowanym Jowejek można jednak odnaleźć echo egzystencjalnych pytań zadawanych przez poetkę: „Żabka. / Kaczuszka. / Kajecik. / Ślizgawka. // Gojonczka. / Ziułtaczka. / Jowejek. / Jowejek. // A potem bryła ciała wypchnięta w przestworza" (Świetlicki 2011: 423, Jowejek).

\section{Akulturacja czy a-kulturacja? (Drugi krąg pytań o „inność”)}

Poszukiwanie sposobów dostosowania się jednostki do zastanej kultury — oto chyba najkrótsza definicja procesu akulturacji. Tymczasem ważnym składnikiem obecnego stadium zachodniej formacji kulturowej staje się zjawisko, które można określić mianem a-kulturacji — dążenia do uzyskania swoistego „zerowego stopnia” doświadczenia „bycia tu”. Stwierdziliśmy już jednak, że zarówno w skali pojedynczego życia, jak i w skali całych społeczeństw ten utopijny stan nigdy nie trwa zbyt długo, prowadząc stopniowo do ponownego „zagospodarowywania” tak opróżnionej przestrzeni. W roku 2011, we wstępie do pełnego wydania swoich napisanych do tej chwili wierszy, Świetlicki wygłosił następującą deklarację:

Poezję robi się przeciw. Przeciw Instytucji, jakkolwiek by się nie nazywała. Przeciw każdej władzy. Przeciw niesprawiedliwości. Przeciw głupocie. Przeciw złym ludziom. Poezja jest ryzykiem. Poezja jest odwagą. Poezja jest niebezpieczna. Wszystko inne to łatwo przetłumaczalne na wiele języków świata bajdurzenie. I tyle. (Świetlicki 2011: 5, Wstęp) 
Ów wyartykułowany przez pięćdziesięcioletniego poetę, nieco naiwnie brzmiący manifest przypomina $\mathrm{z}$ pozoru anarchistyczny wydźwięk napisanego wiele lat wcześniej wiersza Brejkanie, rozpoczynający się od słów: „Dzisiaj — / dostałem list od Papieża. / [...] / Pisze — / pisze, że we mnie wierzy. // Brejkam wszystkie rule. / Brejkam rule" (Świetlicki 2011: 282, Brejkanie), w którego drugiej części czytamy jednak:

Chwalę imię Pana.

W Babilonie.

Chwalę imię Pana.

Za pieniądze.

Wasze - czyste — niezależne

— pieniądze.

Żona.

Dzieci.

Dom postawić.

W Babilonie.

Żona.

Dzieci.

Wanda.

Mieczysławek.

Halina.

Brejkam wszystkie rule.

W Babilonie.

Wasze - czyste

— niezależne pieniądze -

(Świetlicki 2011: 282-283, Brejkanie)

„Babilon”, „korporacja”, „supermarket” to jednak nie tylko topoi kontrkulturowej świadomości Stanów Zjednoczonych, Niemiec czy Francji, ale odkrywanie „tu”, „u nas”, „za oknem”, niepokojących krajobrazów nowej tożsamości. Częste odwoływanie się przez Świetlickiego do tych, kształtujących współczesne kulturowe sensy miejsc wspólnych ma wydźwięk „antyukładowy”: poeta ośmiesza „skarlenie” ambicji i aspiracji młodych ludzi (pisze z perspektywy mężczyzny), które sprowadzają się do wyobrażeń o „małej stabilizacji” — „żony, dzieci, własnego dachu nad głową”, wymagającej przekierowania wyobraźni na tory „korporacyjne”. Chociaż poeta nie pyta o przyczyny takiego stanu rzeczy, to jednak z niepokojem dostrzega proces degradacji życia społecznego, ograniczającego się do masowej konsumpcji jego standardowych, zunifikowanych produktów.

Także Barbara Gruszka-Zych stosuje poetycką taktykę „oczyszczenia” swojej relacji ze światem. Jej strategia nie jest jednak zbudowana na zasadzie dychoto- 
mii, lecz polega na odszukiwaniu „znaków sensu” w subtelnych sygnałach, jakie wychwytuje ona z otaczającego ją świata rzeczy i zdarzeń, ale przede wszystkim tych, które otrzymuje od innych ludzi. Niechętnie definiuje istotę swojej twórczej praktyki, jednak w wierszu, opublikowanym w latach 90. stwierdza, że poezja jest działalnością „pomagają[cą słyszeć tych którym brakło głosu” (Gruszka-Zych 1997: 23, wiersz). Bunt nie jest jej naturą, choć daleka jest od postawy bierności; jej protest przeciwko „złym praktykom” świata wyraża się w postawie, którą można by określić jako amplifikację głosu małych znaków. Wychodząc od najprostszych, najbardziej „ubogich” symboli, stopniowo rozwija je w aktach poetyckiej hermeneutyki, przełamując ich jednostkowy, efemeryczny wymiar i otwierając je na intersubiektywną nadzieję sensu.

\section{„Jaka ojczyzna”? „Jaka Polska”? — trzeci krąg pytań o obcość i przynależność}

Wiele wierszy Marcina Świetlickiego ma w tytule słowo „Polska”. W typowy dla siebie, przewrotny sposób poeta mówi, że właściwie cała jego twórczość jest polityczna. Jednak ojczyzna to obszar symbolicznych konotacji, który wydaje mu się nad wyraz niebezpieczny, szczególnie z chwilą, gdy zaczyna się definiować poprzez jakiekolwiek, nacechowane emocjonalnie znaki wspólnoty:

Państwo świętuje i świętują państwo,

Obchody i odchody.

Podchody z pochodniami na dnie

(Świetlicki 2013: 22, Polska 5)

Świętują „oni”, cieszący się swoim poczuciem „bycia razem” (ergo: przeciw komuś?), podczas gdy samotne „ja” (jak w przywołanym wcześniej wierszu Jacques'a Préverta) jest tu czynnikiem obcym, narażonym na potencjalną agresję „zaangażowanego” tłumu — zdaje się sugerować poeta, serwując czytelnikowi wizję złowrogich, hitlerowskich marszy i zrównując je w dość pospiesznym poetyckim geście z wszelkimi przejawami wspólnotowej tożsamości.

Świetlicki raz po raz zmaga się w swoich tekstach z obsesją „fałszywych znaków" - jak we wczesnym, pochodzącym z roku 1988 roku wierszu, zatytułowanym Dla Jana Polkowskiego (Świetlicki 2011: 61-62)2. Pozornie lustrzanym odbiciem tego szeroko dyskutowanego utworu jest wiersz Jechać, odnoszący się do powrotu do Polski Adama Zagajewskiego na początku lat 2000 (patrz

2 O dyskusji, jaka toczyła się w latach 90. na temat politycznego zaangażowania poezji polskiej i postawy Marcina Świetlickiego w okresie „przełomu” roku 1989 pisał na przykład Dariusz Pawelec (1999). 
Zagajewski 2003). Wydaje się, że w obu przypadkach chodzi bardziej o niebezpiecznie egzaltowany ton literackich wypowiedzi Polkowskiego i Zagajewskiego, a nie jedynie o tropienie „fałszywych znaków przynależności”. Poeta zdaje się zresztą nie dostrzegać różnicy pomiędzy postawami obu twórców, stawiając jakby znak równości pomiędzy podniosłym tonem poezji pierwszego, a napuszonym samozadowoleniem drugiego z nich.

W twórczości Gruszki-Zych niewiele jest jednoznacznych odwołań do ojczystego kraju czy polemicznych tonów, odnoszących się wprost do polskiej rzeczywistości polityczno-społecznej. Jej „bycie tu” nie wymaga być może dodatkowych uzasadnień, opartych na wyraźnie eksponowanym kodzie kulturowym. A jednak, poetka wyraża ostrożne zaufanie wobec symboli, budując je na gruncie przejawów autentycznego doznania solidarności z innymi ludźmi, niezależnie od tego, czy skłonni są porozumiewać się z nią za pomocą wspólnego systemu znaczeń. Do najważniejszych oznak prawdy doświadczenia należy według niej troska o innych, ale także pytanie o sens „krwi umarlych”. Świadczą o tym jej liczne wiersze „szpitalne” oraz tomik Szara jak wróbel, będący poetyckim zapisem towarzyszenia umierającemu ojcu, a także opublikowany w portalu społecznościowym wiersz, poświęcony górnikom z kopalni Wujek: „kiedy ich mordowali / samoloty latały nad Katowicami / 16 grudnia była zimna noc / jak serca tych co wydali rozkaz / czerwona część flagi / napełniła się krwią jak worek / do transfuzji tylko po co / Polsce krew nieżywych" (Gruszka-Zych 2016: ***). To właśnie na gruncie solidarności w obliczu „mocnych” doświadczeń jednostki buduje się, zdaniem poetki, przestrzeń mocnych, wspólnotowych znaczeń.

Żadne z dwojga poetów nie wyraża potrzeby ucieczki do jakiegoś innego świata, nie pragną oni przynależeć do innej przestrzeni geopoetyckiej, niż ta, która od półwiecza kształtuje ich doświadczenie. Urodzoną i dotąd mieszkającą w Czeladzi, często podróżującą poetkę, „biorą [...] w ramiona coraz węższe uliczki / małego miasta" (Gruszka-Zych 2007: 37, ***); Świetlicki chłonie kolejne „klimaty” zamieszkiwanych przez siebie dzielnic Krakowa, odnajdując się za każdym razem w ścisłych ramach tego, co rozpoznawalne, o czym zaświadcza na przykład jego tomik Delta Dietla ${ }^{3}$. „Miniojczyzny” obojga tworzą bezpieczne środowisko naturalne ich poetyckiej wyobraźni, będąc poniekąd mikrokosmosem (kontestowanej w przypadku Świetlickiego) szerszej perspektywy przynależności.

Eksploatacja wizerunku „bycia obcym u siebie” wciąż narażona jest na próbę rzeczywistości. Niezależnie od indywidualnie warunkowanych doświadczeń, sympatii i idiosynkrazji, oboje wybierają „tu i teraz” swojej egzystencji, by mozol-

3 Poeta zarzeka się, że nie lubi podróży i twierdzi, że za granicą nie napisał ani jednego wiersza oraz, że poza Polską czuje się obco - patrz wywiad promujący tom Drobna zmiana, opublikowany 9 listopada 2016 [online]. Dostęp: https://facebook.com/marcinswietlickiINFO [20.12.2016]. 
nie oswajać się z tym, co każde z nich mogłoby uznać za własne. Świetlicki czyni tak nawet wtedy, gdy pisze: „[... ] / Żadne hasła, żadne inicjały i żadne symboliczne obrazki / nie zakrywają mnie i dlatego zupełnie / nie mogą dojść kim jestem / [...] Świat nie oferuje / niczego oprócz blasku. Konkrety pierzchają. / Trzymam się papierosa, żeby się nie zgubić" ('́wietlicki 2016a: Noca z sierpnia na wrzesień).

\section{Dokąd pójść? Ślady i znaki transcendencji}

W poezji Marcina Świetlickiego znajdujemy zaskakująco wiele odniesień do chrześcijańskich symboli religijnych. Bóg Świetlickiego „porzuca czasem szachy” i z zaciekawieniem "wygląda zza chmury” (Świetlicki 2014: 123, Pierwszy dzień średniowiecza $)^{4}$; bawi się ludzikami jak chłopiec żołnierzykami w dziecinnym pokoju (między innymi mrowiącymi się w dole „polaczkami”), etc. Jeśli nawet jest figurą kulturową - jako Bóg Ojciec z brodą ze sklepienia barokowego kościoła, której powierzchowne atrybuty stają się pretekstem dla poetyckiej refleksji na temat hierarchii społecznych znaków - to jednak, jakoś, przewrotnie, ,jest”. Z pozoru całkowicie odseparowany od swych „poddanych”, synonim dyktatorskiej władzy, a jednocześnie łaskawy dawca przywilejów („,...] ty wypadłeś poza / mój dywan, nie dla ciebie drukuję gazety / i kręcę filmy, nie dla ciebie mielą / pieniądze moje banki, nie ciebie ochrania / moja policja, już nic cię nie chroni” (Świetlicki 2011: 10, Piosenka Boga) — może dostrzeże jednak, podniesie i postawi z powrotem na dywanie?

Świetlicki zdaje się prowadzić swoistą grę z Transcendencją, której (o)znaki drażnią go, i kuszą zarazem. Wprawdzie niestrudzenie deklaruje swą niewiarę w możliwość zaufania „mocnym” symbolom i mitom, jednak poszukuje sposobów ujęcia ledwie przeczuwanych sygnałów Mocy, nierzadko czyniąc to w konwencji, porównywalnej do sformułowań mistyki apofatycznej:

Ujść sobie, ubyć z grobu, odmówić, obmyć obie dłonie, wydobyć sobie siebie z siebie, dobić złe ostatecznie, oby. (Świetlicki 2011: 410, Tak się modlit)

Jeśli rzeczywistość daje „zbyt mocne” znaki — poeta wzmaga swą czujność, gdyż mogą one zostać natychmiast włączone w grę emblematów, łatwo wymiennych na aktualną polityczną monetę:

4 Wersja wiersza Pierwszy dzień średniowiecza, śpiewana przez autora z zespołem Świetliki patrz Świetlicki 2015a: 123. 
To ten sam wiatr, który poruszał stronicami Księgi

Przywiał w tej chwili Hostię w ręce Prezydenta

To te same, uparcie te same trupięgi,

To ten sam supermarket i to ten sam cmentarz ${ }^{5}$.

(Świetlicki 2015: 26, To ten sam wiatr)

Powraca pytanie: czy poeta obawia się jedynie — nieuniknionej przecież — możliwości doraźnej manipulacji znakami-symbolami społecznej i religijnej przynależności, czy też kwestionuje samą tęsknotę współczesnego człowieka do znaków transcendencji?

Jeśli Barbara Gruszka-Zych wybiera często za przedmiot swej twórczości symbole możliwie najmniej zapośredniczone (najmniej obarczone perswazyjnymi, jednoznacznymi sensami), to stara się w ten sposób odnaleźć trwałe podstawy własnego stosunku do tradycji i do związanych z nią kodów kulturowych. W jej wierszach relacja ta nie zawsze i nie od razu staje się elementem doświadczenia wspólnotowego: nawet bycie chrześcijaninem i znalezienie się w miejscu kultu nie gwarantuje ani osobistej, ani dzielonej z innymi epifanii transcendencji:

weszłam do kościoła

żeby się pomodlić czyli polecić Bogu

moich bliskich było ich wielu

jak muzyków w orkiestrze

właśnie jakaś orkiestra miała tu próbę

przed wieczornym koncertem

dlatego przeniesiono tabernakulum

i tam gdzie błyszczała hostia zapadła ciemność

szukajcie powtarzał dyrygent co chwilę

przerywając smyczkom tak że muzyka

rwała się jak moja modlitwa

aż wreszcie zawisła ciszą w pełnym kościele

(Gruszka-Zych 2008: 25, ***)

Swoją przynależność do „kodu transcendencji” Gruszka-Zych wydobywa najczęściej z gestów i znaków pozornie „odsymbolicznionej” codzienności:

podałam tacie ciasto obsypane orzechami ziemnymi

$[\ldots]$

5 Czy pomiędzy wszystkimi symbolami, tworzącymi się (lub wytwarzanymi) w kontekście władzy poeta stawia matematyczny znak równości? Wszak w żadnym ze swych wierszy nie odniósł się on na przykład do interesującej, z perspektywy hermeneutyki symboli, próby stworzenia „nowej symboliki” władzy w postaci wizerunku czekoladowego orła i uroczystości, towarzyszących jego prezentacji? 
zamiast słów jedzenie po kawałku dopełnianie siebie światem upieczonym na blasze w czworobocznej formie uniesionym przez tatę do ust w pokornym geście komunii (Gruszka-Zych 2000: 24, ${ }^{* * *}$ )

Z kolei w wierszu, w którym niewinne, skupione przejęcie dziewczynki przed ołtarzem zestawione jest z prawdą milczącego, ulotnego piękna natury, jeszcze dobitniej realizuje się zasada sprzężenia zwrotnego pomiędzy znaczonym i znaczącym symbolu, relacja oparta jednocześnie na prawie analogii i partycypacji:

Dziś o świcie każda gałązka jakby przystępowała do pierwszej komunii w delikatnej bieli szadzi

(Gruszka-Zych 2015: 23, ***)

\section{Droga pośród znaków}

Pomimo wszelkich dzielących ich różnic, jednym ze wspólnych mianowników twórczości obojga poetów jest podejmowana przez nich próba redefinicji ich stosunku do własnej kultury jako poszukiwanie tego, co jawi im się jako własne. W przypadku Marcina Świetlickiego niechęć do integracji (,jaka rodzina?”, ,jaki Bóg?” ,jaka ojczyzna?”) jest gestem obronnym wobec atakującego zewsząd natłoku znaczeń, domagających się „podjęcia decyzji”, opowiedzenia się „za” lub „przeciw”. Spierając się poetycko z zastanymi symbolami kultury, Świetlicki chciałby zarówno zaprotestować przeciwko ich skostnieniu, jak i ukazać — poprzez zabieg swoistej wiwisekcji — efekty ich ponowoczesnej, migotliwej efemeryczności. Na tej (pozornej?) niekonsekwencji buduje on niejasną, głęboko skrywaną nadzieję odnalezienia jakichkolwiek „znaków prawdziwych”.

Można by sądzić, że powyższe dylematy w znacznie mniejszym stopniu oddziałują na poetykę Barbary Gruszki-Zych. Jednak i ona prowadzi swoistą grę z symbolami, którym daje jedynie ograniczony kredyt zaufania: praktyka ta polega na intuicyjnym wychwyceniu tych, które wydają się być mocniejszymi, niż inne, a następnie poddaniu ich „próbie trwałości” w świetle kolejnych egzystencjalnych zdarzeń.

${ }^{6}$ Jego książka poetycka z roku 2016, zatytułowana Drobna zmiana zdaje się częściowo modyfikować taką postawę, wyraźniej niż dotąd określając miejsce poety w przestrzeni aktualnej (w czasie, gdy pisał wiersze tego tomu) polskiej debaty medialno-politycznej. Autor potwierdza to po części w rozmowie, promującej jego tomik poetycki, deklarując między innymi, że „człowiek musi wybierać”, po chwili stwierdzając z kolei, że „nie wie[m], komu wierzyć” — rozmowa z Marcinem Świetlickim, przeprowadzona w wydawnictwie a5, 9 listopada 2016 roku (Świetlicki 2016b). 
Zajmowana przez Świetlickiego i Gruszkę-Zych indywidualistyczna postawa wobec znaków, jakie wysyła im świat, wyraża się w podejmowanych przez nich próbach odróżnienia symboli istotnych, które nie poddają się dyktatowi chwilowego, koniunkturalnego sensu od symboli skarlałych - kuszących swym blichtrem, lecz istotowo fałszywych. Wbrew jednoznacznej diagnozie współczesnej sztuki, jaką proponuje Jean Baudrillard i którą aprobująco cytuje Zygmunt Bauman („Wizje artysty nie przedstawiają, lecz symulują — zaś „symulacja odnosi się do świata pozbawionego odnośników, świata, w jakim wszystkie odnośniki wyginęły" (Baudrillard, cyt. za: Bauman 2000: 184), ani Marcin Świetlicki, ani Barbara Gruszka-Zych nie symulują swojej relacji ze światem, ale szanują łączącą ich z nim więź. Nie porzucają też swoich siedzib, choć ceną jest nieustający trud oswajania się z tym, co własne.

\section{BIBLIOGRAFIA:}

Apollinaire Guillaume. 1975. Wybór poezji. Oprac. Jerzy Kwiatkowski. Warszawa: Ossolineum. Strefa. Przeł. Adam Ważyk. S. 37-48.

Barthes Roland. 1978. Leçon: leçon inaugurale de la chaire de sémiologie littéraire du Collège de France : prononcée le 7 janvier 1977. Paris: Le Seuil.

Barthes Roland. 2000. Mitologie. Przeł. Adam Dziadek. Warszawa: Wydawnictwo KR.

Bauman Zygmunt. 2000. Ponowoczesność jako źródto cierpień. Warszawa: Wydawnictwo Sic!.

Gruszka-Zych Barbara. 1994. Teren prywatny. Katowice: Videograf.

Gruszka-Zych Barbara. 2000. Zapinajac kolczyki. Katowice: Parol.

Gruszka-Zych Barbara. 2007. Ile kosztuje tąka. Katowice: Biblioteka Śląska.

Gruszka-Zych Barbara. 2008. Muchy i ludzie. Katowice: Księgarnia św. Jacka.

Gruszka-Zych Barbara. 2015. Przyrzad do uzdatniania wody. Wrocław: Wydawnictwo Astrum.

Gruszka-Zych Barbara. 2016. Górnicy z kopalni Wujek. [online]. Dostęp: https://facebook.com/barbara.gruszkazych, wpis z 13 grudnia 2016 [20.12.2016].

Pawelec Dariusz. 1999. Oko smoka. O wierszu Marcina Świetlickiego „Dla Jana Polkowskiego". W: Kanonada. Interpretacje wierszy polskich (1939-1989). Red. Aleksander Nawarecki. Katowice: Wydawnictwo Uniwersytetu Śląskiego. S. 168-174.

Niewiadomski Andrzej. 2014. Dlaczego skwery sa idealnie kwadratowe? Przypisy do „Dla Jana Polkowskiego” po ćwierćwieczu. „Ruch Literacki” 2014, z. 6. S. 625-639.

Prévert Jacques. 1978. Walka Jakuba z aniotem. Przeł. Roman Kołoniecki. W: Hugo Friedrich. Struktura nowoczesnej liryki. Przeł. i wstępem opatrzyła Elżbieta Feliksiak. Warszawa: Państwowy Instytut Wydawniczy. S. 311. 
Świetlicki Marcin. 2011. Wiersze. Kraków: Wydawnictwo emg.

Świetlicki Marcin. 2013. Jeden. Kraków: Wydawnictwo emg.

Świetlicki Marcin. 2015. Delta Dietla. Kraków: Wydawnictwo emg.

Świetlicki Marcin. 2015a. Zto, te przeboje. Piosenki 1992-2015. Kraków: Wydawnictwo emg.

Świetlicki Marcin. 2016. Drobna zmiana. Kraków: Wydawnictwo a5.

Świetlicki Marcin. 2016a. Nocą z sierpnia na wrzesień. [online]. Dostęp: https://facebook.com/marcinswietlickiwiersze [1.09.2016].

Świetlicki Marcin. 2016b. Rozmowa z Marcinem Świetlickim. [online]. Dostęp: https:// facebook.com/marcinswietlickiINFO [18.12.2016].

Zagajewski Adam. 2003. Powrót. Kraków: Znak.

Stanistaw Jasionowicz

\title{
NATIVE STRANGERS? MARCIN ŚWIETLICKI AND BARBARA GRUSZKA-ZYCH FACING SIGNS OF BELONGING
}

\author{
(summary)
}

The article is a reflection on the symbols through which the modern experience of cultural belonging is expressed and on the motivations behind their contestation. Examples of selected themes that Marcin Świetlicki and Barbara Gruszka-Zych explore in their writing are used to examine the poetic quest to overcome feelings of alienation in one's own cultural milieu. In spite of the differences between the two poets, both address the problems facing the contemporary consciousness of Western man, split between the desire to complete the process of deconstructing his own universal "identifying signs" and the need to creatively explore the process of symbolization itself.

The issue of "internal acculturation," as a particular case within the topic of acculturation as a whole, is also correlated to examples drawn from Francophone poetry.

\section{KEYWORDS}

Marcin Świetlicki; Barbara Gruszka-Zych; contemporary Polish poetry; French poetry; sign; symbol; belonging; alienation; culture; acculturation; a-culturation 